\title{
EFFECT OF Mg CONTENTS ON THE MECHANICAL PROPRIETIES AND PRECIPITATION KINETICS IN Al-3.3 WT.\% Cu ALLOY
}

\author{
M. Fatmi ${ }^{1, *}$, A. Ouali ${ }^{2}$, A. Djemli ${ }^{2}$, T. Chihi ${ }^{1}$, M.A. Ghebouli ${ }^{3}$, \\ F. Sahnoune ${ }^{1,2}$, B. Ghebouli ${ }^{4}$, B. Barka ${ }^{5}$ \\ ${ }^{1}$ Research Unit on Emerging Materials (RUEM), University Ferhat \\ Abbas of Setif 1, 19000, Algeria \\ ${ }^{2}$ Department of Physics, Faculty of Sciences, University of Mohamed Boudiaf, M'sila, \\ 28000, Algeria. \\ ${ }^{3}$ Department of Chemistry, Faculty of Technology, University of Mohamed \\ Boudiaf, M'sila, 28000, Algeria. \\ ${ }^{4}$ Laboratory of Studies of Surfaces and Interfaces of Solid Materials, \\ University Ferhat Abbas of Setif 1, 19000, Algeria \\ ${ }^{5}$ Laboratory of growth and characterization of new semiconductors, Faculty of \\ Technonology, University of Ferhat Abbas, Setif 01, 19000, Algeria
}

Received 25.05.2017

Accepted 04.10.2017

\begin{abstract}
The effect of additional $\mathrm{Mg}$ on the microstructure, mechanical properties, and transformation kinetics during aging in $\mathrm{Al}-3.3 \mathrm{wt} . \% \mathrm{Cu}$ alloy was studied. The compositions and microstructure were examined by X-ray diffraction, Differential scanning calorimetry (DSC) and scanning electron microscope (SEM) with energy dispersive X-ray spectroscopy (EDS). The results show that the $\mathrm{Mg}$ in the $\mathrm{Al}-\mathrm{Cu}$ alloy mainly precipitated to the grain boundaries during the process of transformation and formed a ternary $\mathrm{Al}_{2} \mathrm{CuMg}$ metallic compound and the rate of discontinuous precipitation reaction decreases with increasing concentration of $\mathrm{Mg}$. The activation energy of crystallization was evaluated by applying the Kissinger equation.
\end{abstract} DSC.

Keywords: $\mathrm{Al}-\mathrm{Cu}-\mathrm{Mg}$ alloys; Discontinuous precipitation; Activation energy;

\section{Introduction}

The aluminum has excellent mechanical properties in the presence of alloying elements, mainly due to the precipitation hardening (e.g., $\mathrm{Al}-\mathrm{Cu}(\mathrm{Mg})$ alloys). These

\footnotetext{
* Corresponding author: Messaoud Fatmi,fatmimessaoud@yahoo.fr
} 
alloys and materials are widely used in the aeronautics field [1-5]. For a concentration of $\mathrm{Cu}$ less than $4 \%$, the $\mathrm{Al}-\mathrm{Cu}$ and $\mathrm{Al}-\mathrm{Cu}-\mathrm{Mg}$ phase diagrams show the formation of a solid solution $\alpha$. Increasing the concentration leads to precipitation of copper in the form of Guinier Preston zones (GP1 and GP2) and the first compound $\mathrm{Al}_{2} \mathrm{Cu}\left(\theta^{\prime}\right.$ metastable, then $\theta$ stable), and phases ( $\mathrm{S}^{\prime}$ metastable, then $\mathrm{S}$ stable) in $\mathrm{Al}-\mathrm{Cu}-\mathrm{Mg}$ alloys [6-7].

The precipitation sequence in the $\mathrm{Al}-\mathrm{Cu}-\mathrm{Mg}$ system can be presented as

$$
\operatorname{SSSS}\left(\alpha_{o}\right) \rightarrow G P B \rightarrow S^{\prime \prime} \rightarrow S^{\prime} \rightarrow S
$$

where SSSS $\left(\alpha_{0}\right)$ is the supersaturated solid solution obtained after solution treatment and quenching. S. C. Wang and M. J. Starink, investigated the effect of heat treatments and deformation on the formation of two variants of $S$ phase precipitation in an $\mathrm{Al}-4.2 \mathrm{Cu}-1.5 \mathrm{Mg}-0.6 \mathrm{Mn}-0.5 \mathrm{Si}$ (AA2024) and $\mathrm{Al}-4.2 \mathrm{Cu}-1.5 \mathrm{Mg}-0.6 \mathrm{Mn}-0.08 \mathrm{Si}$ (AA2324) (wt.\%) alloys using transmission electron microscopy (TEM) and a scanning electron microscopy (SEM) analysis [7]. The DSC analysis of the as-solution treated samples shows two distinct exothermic peaks in the range from 250 to $350{ }^{\circ} \mathrm{C}$. An S phase with a composition of $\mathrm{Al}_{2} \mathrm{CuMg}$ has been determined as an orthorhombic $\mathrm{Cmcm}$ structure with lattice parameters: $a_{\mathrm{S}}=0.400 \mathrm{~nm}, \mathrm{~b}_{\mathrm{S}}=0.923 \mathrm{~nm}, \mathrm{c}_{\mathrm{S}}=0.714 \mathrm{~nm}$ [8-9]. A range of structures has been proposed for GPB, S”, S ', and S as shown in Table 1 [10-14].

Table 1. Previous reported and proposed structures for GPB and S', S' and S phases.

\begin{tabular}{|c|c|c|c|c|}
\hline Crystallographic structure & Composition & $\begin{array}{c}\text { Experimental } \\
\text { data supporting } \\
\text { model }\end{array}$ & $\begin{array}{l}\text { Structure } \\
\text { name }\end{array}$ & Reference \\
\hline $\begin{array}{l}\text { Orthorhombic, } \\
a=0.405 \mathrm{~nm}, \\
b=0.906 \mathrm{~nm} \text { and } \\
c=0.725 \mathrm{~nm}\end{array}$ & $\mathrm{Al} 2 \mathrm{CuMg}$ & Proposed & GPB & {$[10,11]$} \\
\hline $\begin{array}{l}\text { Tetragonal, } \\
a=0.405 \mathrm{~nm}, \\
c=0.81 \mathrm{~nm}, \mathrm{P} 4 / \mathrm{nbm}\end{array}$ & $\mathrm{A} 12 \mathrm{CuMg}$ & FPTEC & GPB & [12] \\
\hline $\begin{array}{l}\text { Monoclinic, } \\
a=0.400 \mathrm{~nm}, \\
b=0.925 \mathrm{~nm}, \\
c=0.718 \mathrm{~nm}, \alpha=88.6^{\circ}\end{array}$ & $\mathrm{Al} 2 \mathrm{CuMg}$ & XRD & $S^{\prime \prime}$ & {$[13]$} \\
\hline $\begin{array}{l}\text { Orthorhombic, } \\
a=0.405 \mathrm{~nm}, \\
b=0.405 \mathrm{~nm} \text { and } \\
c=0.81 \mathrm{~nm}, \mathrm{Imm} 2\end{array}$ & $\mathrm{Al} 2 \mathrm{CuMg}$ & TEM & $S^{\prime \prime}$ & {$[14]$} \\
\hline $\begin{array}{l}\text { Orthorhombic, } \\
a=0.400 \mathrm{~nm}, \\
b=0.461 \mathrm{~nm}, \\
c=0.718 \mathrm{~nm}, \text { Pmm } 2\end{array}$ & $\mathrm{Al} 2 \mathrm{CuMg}$ & HREM & $S^{\prime}$ & {$[8]$} \\
\hline $\begin{array}{l}\text { Orthorhombic, } \\
a=0.400 \mathrm{~nm}, \\
b=0.923 \mathrm{~nm}, \\
c=0.714 \mathrm{~nm}, \mathrm{Cmcm}\end{array}$ & $\mathrm{Al} 2 \mathrm{CuMg}$ & XRD & $S$ & [15] \\
\hline
\end{tabular}


Nanodiffraction and HREM technology by J.C.L. Yan et al. have been used to determine the crystal structure of the $\mathrm{S}^{\prime}$ phase $\left(\mathrm{Al}_{2} \mathrm{CuMg}\right)$, and conclude it, at $200{ }^{\circ} \mathrm{C}$ for times ranging from 10-10.000 $\mathrm{h}$, there appears to be no difference in crystal structure between S ' and equilibrium S phase [15]. Recent work of R.K.W. Marceau et al. show diffusion couple after aging for $5 \mathrm{~min}$ at $200{ }^{\circ} \mathrm{C}$ in $\mathrm{Al}-1 \mathrm{Cu}-0.76 \mathrm{Mg}$ and $\mathrm{Al}-2.18 \mathrm{Cu}-$ $1.66 \mathrm{Mg}$ (wt.\%); above a critical $\mathrm{Cu}$ content the rapid hardening phenomena diminishes [16].

The aim of this research is to study the effect of $\mathrm{Mg}$ content on the microstructure and mechanical properties of $\mathrm{Al}-\mathrm{Cu}$ alloy. The possible effect mechanism will also be discussed.

\section{Experimental methods}

Two commercials purity $\mathrm{Al}-\mathrm{Cu}-\mathrm{Mg}$ alloys ingots have been studied; the compositions are shown in Table 2.

Table 2. Compositions of the alloys (wt.\%).

\begin{tabular}{llllll}
\hline & \multicolumn{5}{c}{ Element } \\
& $\mathrm{Cu}$ & $\mathrm{Mg}$ & $\mathrm{Fe}$ & $\mathrm{Si}$ & $\mathrm{Al}$ \\
\hline $\mathrm{S} 1$ & 3.3 & 0.98 & 0.08 & 0.01 & Bal. \\
\hline $\mathrm{S} 2$ & 3.3 & 2.03 & 0.06 & 0.01 & Bal. \\
\hline
\end{tabular}

Specimens with the size of $10 \mathrm{~mm} \times 10 \mathrm{~mm} \times 12 \mathrm{~mm}$ were wired-cut from the center of the ingot. The specimens were homogenized at $470^{\circ} \mathrm{C}$ for one week and quenched in water. Microstructure, morphologies of fracture surface and compositions of tested alloys were analyzed by Scanning Electron Microscopy (SEM) (JEOL 2000FX) equipped with energy dispersive spectroscopy (EDS). Phase identification of the alloys was further confirmed by analyzing X-ray diffraction patterns generated by PAN alytical X'Pert PRO diffractometer. $\mathrm{CuK} \alpha$ radiation and a speed of $1 \%$ min were used. The DSC measurements were performed with a NETZSCH 200 PC DSC. Vickers hardness is one of the most testing techniques and scientists. It is a form of microhardness that uses a diamond indenter and is suitable for a wide range of materials. A Yukon 2500 device was used in the microhardness measurements.

\section{Results and discussion}

The as-quenched microstructure

The as-quenched microstructures are shown in Fig. 1. It is a typical structure that consists of the fine precipitates with a grain boundary. Fig. 2 represents a typical EDS spectrum of the presents alloys in the as-quenched condition. The quantitative analysis of six different EDS spectra indicated that the average chemical compositions were: $\mathrm{Al}$ $3.3 \pm 0.3$ wt. $\%-\mathrm{Cu}-0.96 \pm 0.2$ wt.\% $\mathrm{Mg}$ and $\mathrm{Al}-3.28 \pm 0.1$ wt.\% $\mathrm{Cu}-1.98 \pm 0.4$ wt.\% $\mathrm{Mg}$ respectively. 

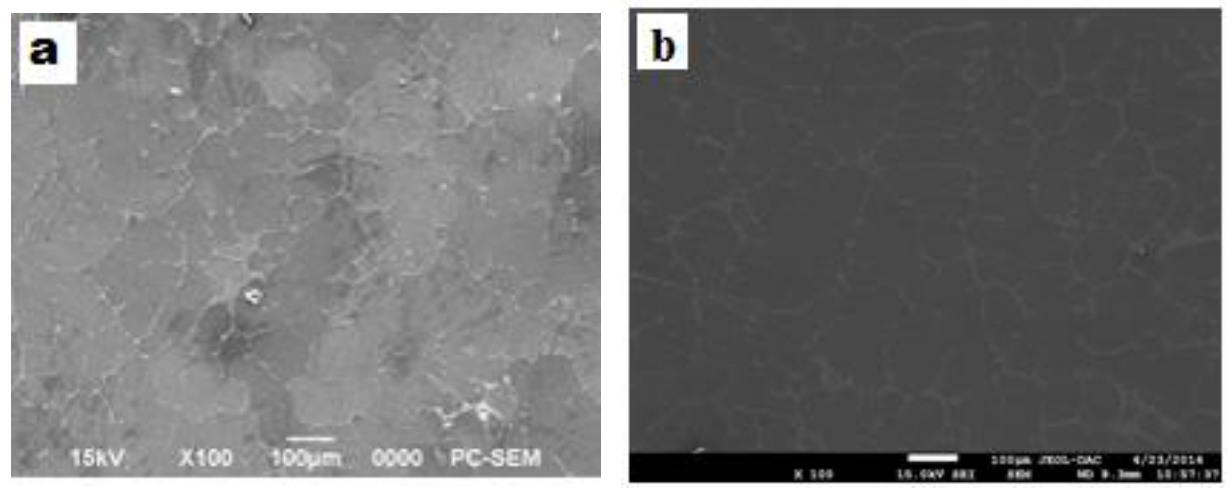

Fig. 1. Microstructures of as-quenched Al-3.3wt.\% Cu-1wt.\%Mg (a) and $\mathrm{Al}-3.3 w t . \% \mathrm{Cu}-2 \mathrm{wt.} \% \mathrm{Mg}(\mathrm{b})$ alloys.

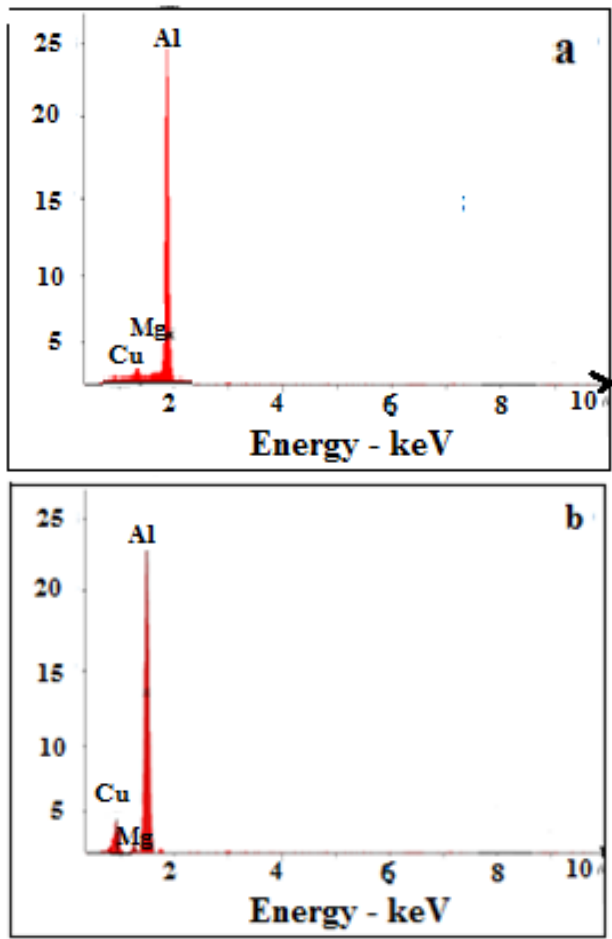

Fig. 2. A typical EDS profile of $\mathrm{Al}-3.3 w t . \% \mathrm{Cu}-1 \mathrm{wt} . \% \mathrm{Mg}(\mathrm{a})$ and Al-3.3wt.\%Cu-2wt.\%Mg (b) alloys in the as-quenched conditions.

For studying the heat treatment effect on the discontinuous precipitation in $\mathrm{Al}-3.3$ wt.\% $\mathrm{Cu}-1 \mathrm{wt} . \% \mathrm{Mg}$ and $\mathrm{Al}-3.3 \mathrm{wt} . \% \mathrm{Cu}-2 \mathrm{wt} . \% \mathrm{Mg}$ alloys, the samples are homogenized at $470{ }^{\circ} \mathrm{C}$ for one week and quenched in water. In this part of the investigation, we present the results of differential scanning calorimetry (DSC) in 
nonisothermal conditions, previously homogenized and quenched (Fig. 3 and Fig. 4); and age at different heating rates $\left(2,5\right.$, and $\left.10^{\circ} \mathrm{C} / \mathrm{min}\right)$.

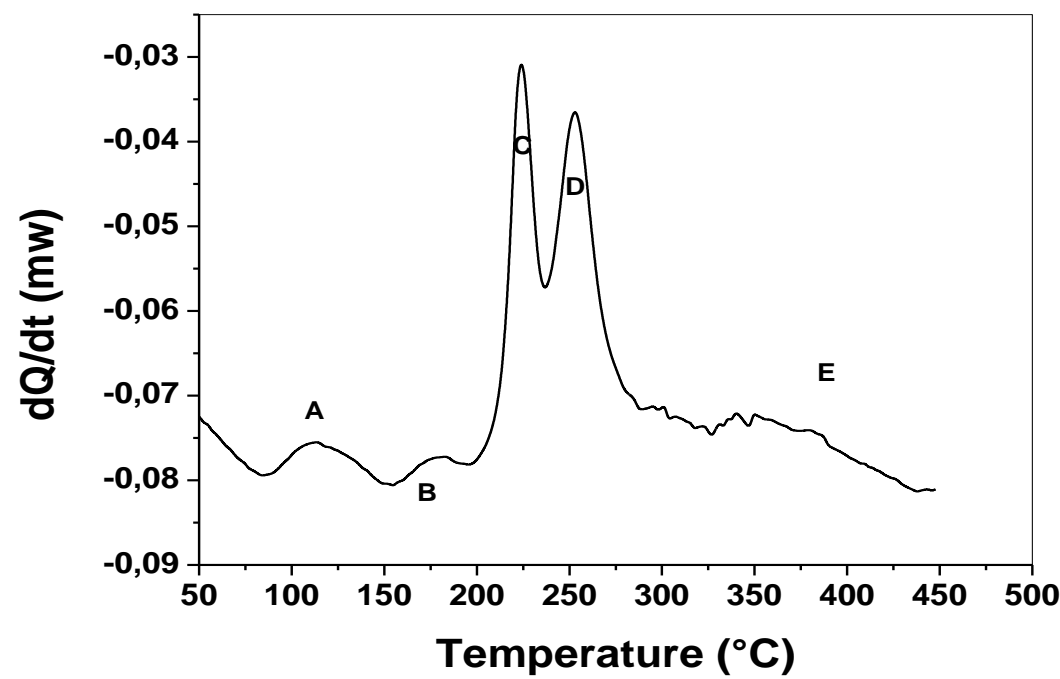

Fig. 3. DSC curve of $\mathrm{Al}-3.3 \mathrm{wt} . \% \mathrm{Cu}-1 \mathrm{wt} . \% \mathrm{Mg}$ alloy, homogenized one week at $470{ }^{\circ} \mathrm{C}$, quenched in water and heated in the range $25-450{ }^{\circ} \mathrm{C}$ (heating rate $2{ }^{\circ} \mathrm{C} \cdot \mathrm{min}^{-1}$ ).

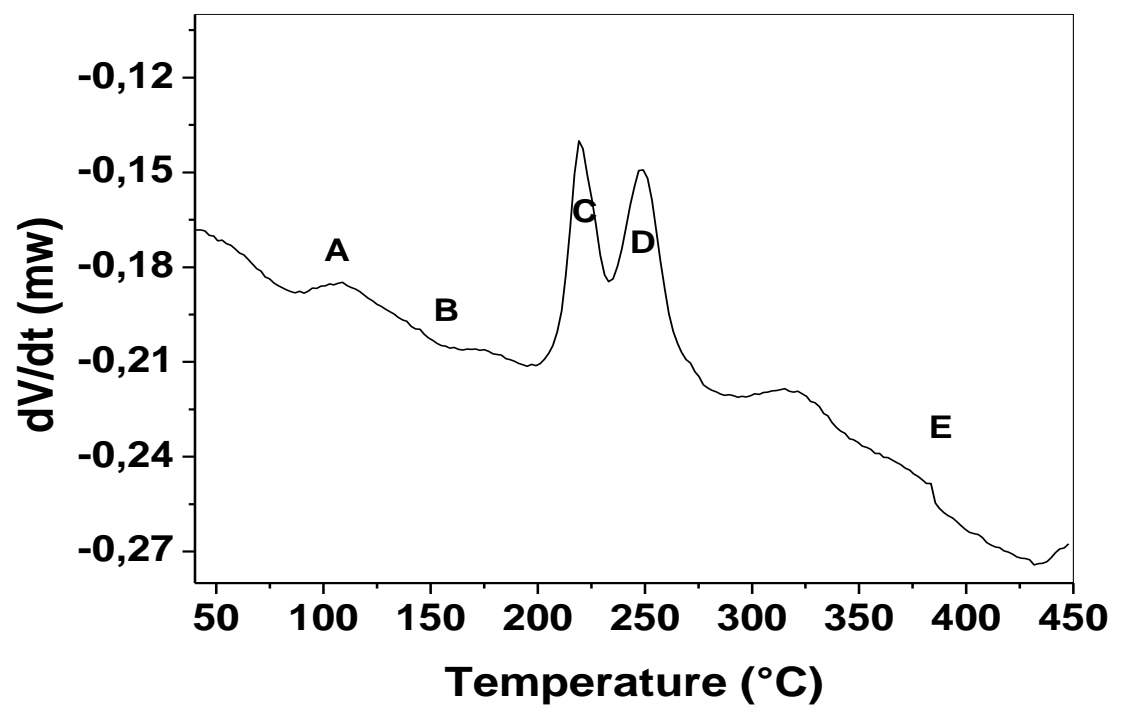

Fig. 4. DSC curve of $\mathrm{Al}-3.3 \mathrm{wt} . \% \mathrm{Cu}-2 \mathrm{wt} . \% \mathrm{Mg}$ alloy, homogenized one week at $470{ }^{\circ} \mathrm{C}$, quenched in water and heated in the range $25-450{ }^{\circ} \mathrm{C}$ (heating rate $2{ }^{\circ} \mathrm{C} \cdot \mathrm{min}^{-1}$ ). 
Five main effects may be identified in these thermograms [17-19] an exothermic peak; A, between 60 and $130{ }^{\circ} \mathrm{C}$ that occurred due to the formation of co-clusters [20, 21]; an endothermic effect, $\mathrm{B}$, between 130 and $170{ }^{\circ} \mathrm{C}$, may be attributed to $\mathrm{Cu}-\mathrm{Mg}$ cocluster dissolution (with possibly some GPB2 dissolution); two exothermic peaks effect, $\mathrm{C}$, and D between about 200 and $300{ }^{\circ} \mathrm{C}$, are attributed to the formation of $\mathrm{S}^{\prime}$ ' and $\mathrm{S}$ phases precipitates respectively; a broad endothermic effect, E, at 300 to $450{ }^{\circ} \mathrm{C}$ is identified as progressive dissolution of the $S^{\prime}$ and $S$ precipitates $[22,23]$.

To determine the activation energy $E_{a}$ of $S^{\text {‘ }}$ and $S$ phases of our alloys we use the Kissinger method, this method relies on the assumption that, during the temperature increase, the reaction passes through a maximum before decreasing, using the following relation [24]:

$$
\ln \left(\frac{V}{T_{m}^{2}}\right)=-\frac{E_{a}}{T_{m} \cdot R}+C
$$

where $\mathrm{C}$ is constant, at the maximum rate of transformation which corresponds to the maximum at the DSC peak $T=T_{\mathrm{m}}\left(\mathrm{d}^{2} \mathrm{y} / \mathrm{dt}^{2}=0\right)$ and $\mathrm{R}$, the perfect gas constant $(8.314$ $\mathrm{J} / \mathrm{mol} \cdot \mathrm{K})$.

The maximum temperatures of reactions were determined from the slopes of the DSC curves. The activation energy for the formation of the $\mathrm{S}^{\text {‘ }}$ and $\mathrm{S}$ phases (Al2 CuMg) under nonisothermal conditions was calculated from the slope of $\ln \left(\frac{V}{T_{m}^{2}}\right)$ - function of $1 / \mathrm{Tm}$.

The value of $E_{a}$ may be calculated from the slope of each curve it is shown in this following Table 3; these values are in good accordance with the literature [25].

Table 3. The activation energies of S' and S phases of Al-3.3wt.\% Culwt.\%Mg and Al-3.3wt.\% Cu2wt.\%Mg alloys.

\begin{tabular}{ccc}
\hline & Phase & $E_{a}(\mathrm{~kJ} / \mathrm{mol})$ study \\
\hline \multirow{2}{*}{$\mathrm{Al}-3.3 \% \mathrm{Cu} 1 \% \mathrm{Mg}$} & $\mathrm{S}^{\prime}$ & $150.71 \pm 2.44$ \\
& $\mathrm{~S}$ & $158.44 \pm 1.62$ \\
\hline \multirow{2}{*}{$\mathrm{Al}-3.3 \% \mathrm{Cu} 2 \% \mathrm{Mg}$} & $\mathrm{S}^{\prime}$ & $151.82 \pm 1.99$ \\
& $\mathrm{~S}$ & $157.82 \pm 2.05$ \\
\hline
\end{tabular}

The results of the heating rate and $\mathrm{Mg}$ concentration effect on precipitation are presented in the relative volume fraction versus temperatures (Fig. 5), this figure shows sigmoidal curves at different temperatures for the discontinuous precipitation (DP). It is clear that as the concentration of $\mathrm{Mg}$ increases, the rate of DP reaction decreases (shift curves on basis temperatures). 

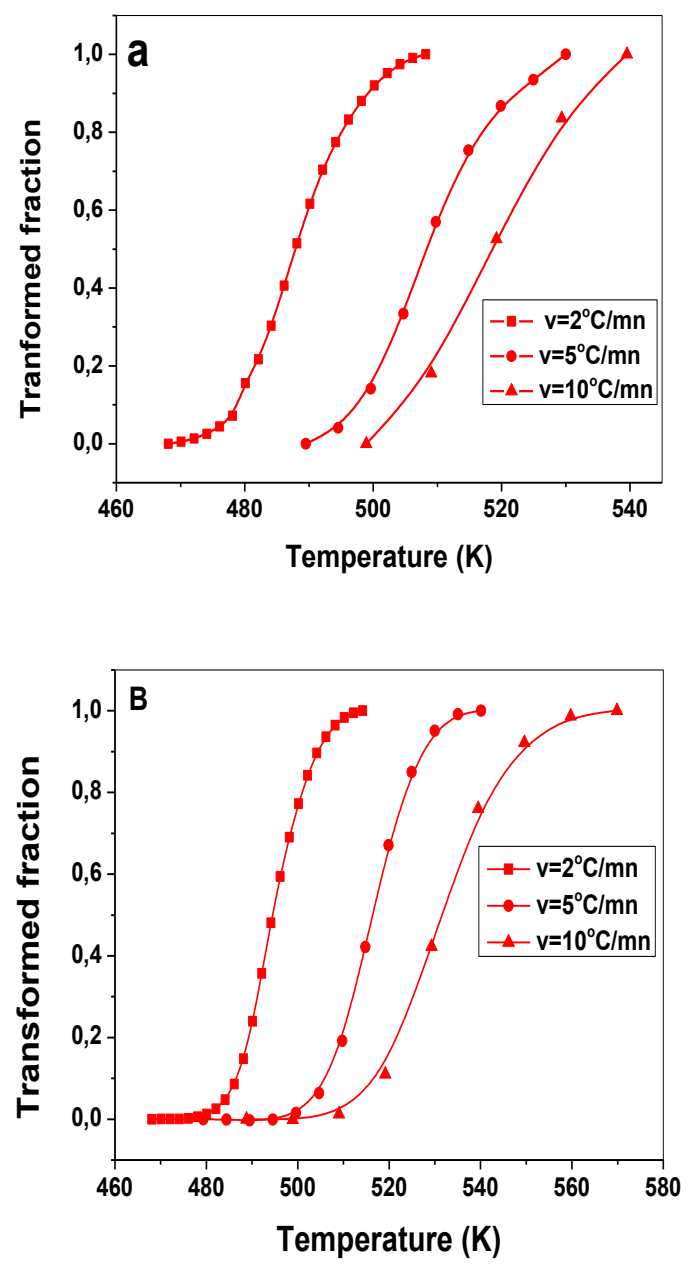

Fig. 5. Transformed fraction as a function of the temperature at various heating rate of $\mathrm{Al}-3.3 w t . \% \mathrm{Cu}-1 \mathrm{wt} . \% \mathrm{Mg}(\mathrm{a})$ and $\mathrm{Al}-3.3 \mathrm{wt} . \% \mathrm{Cu}-2 \mathrm{wt} . \% \mathrm{Mg}(\mathrm{b})$ alloys of S' phase.

To determinate the Avrami exponent we used the formula, $n=\frac{2.5 R}{\Delta T E_{a}} T_{m}^{2}$ [26]:

where are: $\Delta \mathrm{T}-\mathrm{The}$ width at half maximum, $\mathrm{E}_{\mathrm{a}}-$ activation energy and $\mathrm{R}-$ ideal gas constant.

The Table 4. shows the values of Avrami exponent (n). Avrami analysis was utilized to study the overall bulk crystallization kinetics after a specific thermal history. The Avrami exponent evaluated empirically, generally between 1 and 4 . In the present study, the mean value of Avrami coefficient (n) for $\mathrm{S}^{\prime}$ and $\mathrm{S}$ phases is 1.41 and 1.42 respectively; which may correspond to phase transformation mechanism driven by the diffusion. It has been found, that like any other diffusion controlled nucleation and growth 
process, the reaction front velocity in DP usually records an 'inverse-C' variation with temperature [27].

Table 4. Avrami exponent of S' and S phases of Al-3.3wt.\%Culwt\%Mg and Al-3.3wt.\% Cu2wt.\% Mg alloys.

\begin{tabular}{lcccc}
\hline Alloy & \multicolumn{2}{c}{$\mathrm{Al}-3.3 \% \mathrm{Cu}-1 \% \mathrm{Mg}$} & \multicolumn{2}{c}{$\mathrm{Al}-3.3 \% \mathrm{Cu}-2 \% \mathrm{Mg}$} \\
\hline Phase & $\mathrm{S}^{\prime}$ & $\mathrm{S}$ & $\mathrm{S}$ & $\mathrm{S}$ \\
\hline$n$ & 1.50 & 1.31 & 1.46 & 1.37 \\
\hline
\end{tabular}

It is suggested that atomic mobility is essential for the time-dependent nucleation. It is noticed that the peak moves towards basis temperatures as much as the concentration of $\mathrm{Mg}$ increases.

\section{After DSC treatment}

The nonisothermal treatment effect on the transformation of precipitation in $\mathrm{Al}-$ $3.3 \mathrm{wt} . \% \mathrm{Cu} 1 \mathrm{wt} . \% \mathrm{Mg}$ and $\mathrm{Al}-3.3 \mathrm{wt} . \% \mathrm{Cu} 2 \mathrm{wt} . \% \mathrm{Mg}$ was examined before and after DSC treatments. The initial samples are homogenized at $470^{\circ} \mathrm{C}$ for one week and quenched in water. The X-ray diffraction spectrum of this quenched alloy which corresponds to supersaturated solid solution $\alpha_{0}$ is shown in Fig. 6 (a). The second nonisothermal treatment applied on quenched alloy is performed by DSC analysis, from room temperature to $470{ }^{\circ} \mathrm{C}$ with heating rate $2{ }^{\circ} \mathrm{C} / \mathrm{min}$. The DSC curves show an exothermal peak that corresponds to energy dissipation during the discontinuous precipitation. The formation of this new $\mathrm{S}$ phase after last treatment is detected by the X-ray diffraction, where the $\mathrm{S}$ phase $\left(\mathrm{Al}_{2} \mathrm{CuMg}\right)$ peaks are present in the spectrum, Fig. $6(\mathrm{~b}, \mathrm{c})$.

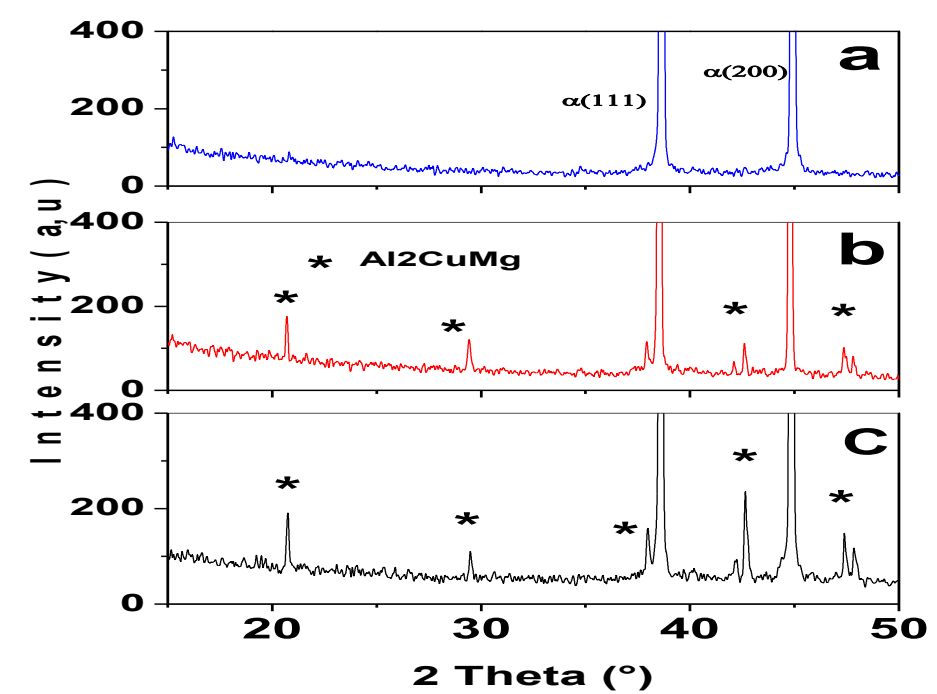

Fig. 6. X-ray diffraction spectrum of Al-3.3wt.\% Cu-1wt.\% Mg alloy, homogenized at $470{ }^{\circ} \mathrm{C}$ for one week and quenched in water (a), after DSC treatment $\left(25-450{ }^{\circ} \mathrm{C}\right.$, $v=2{ }^{\circ} \mathrm{C} . \mathrm{min}^{-1}$ ) of $\mathrm{Al}-3.3 \mathrm{wt} . \% \mathrm{Culwt} \% \mathrm{Mg}(\mathrm{b})$, and $\mathrm{Al}-3.3 \mathrm{wt} . \% \mathrm{Cu} 2 \mathrm{wt} . \% \mathrm{Mg}$ (c) alloys. 
However, differential scanning calorimetry (DSC) and XRD analysis, justifies the precipitation of new phases corresponding to the intermetallic phases $S^{\prime}$ and $S$ $\left(\mathrm{Al}_{2} \mathrm{CuMg}\right)$. The grain size has not changed in the same grains observed in the quenched state (bellow DSC treatment). The SEM and EDS analysis revealed these precipitates of different types marked with $\mathrm{B}$ and $\mathrm{C}$ in Fig. 7. The chemical compositions of the phases are presented in the correspondent EDS curves. The phase marked by $\mathrm{B}$ and $\mathrm{C}$ is found to have the following composition: $14 \% \mathrm{Cu}, 10 \% \mathrm{Mg}$ and balance $\mathrm{Al}$ and $40 \% \mathrm{Cu}, 3 \%$ $\mathrm{Mg}$ and balance $\mathrm{Al}$ of $\mathrm{Al}-3.3 \mathrm{wt} . \% \mathrm{Cu} 1 \mathrm{wt} . \% \mathrm{Mg}$ and $\mathrm{Al}-3.3 \mathrm{wt} . \% \mathrm{Cu} 2 \mathrm{wt} . \% \mathrm{Mg}$ respectively, which is consistent with the $\mathrm{S}$ phase.
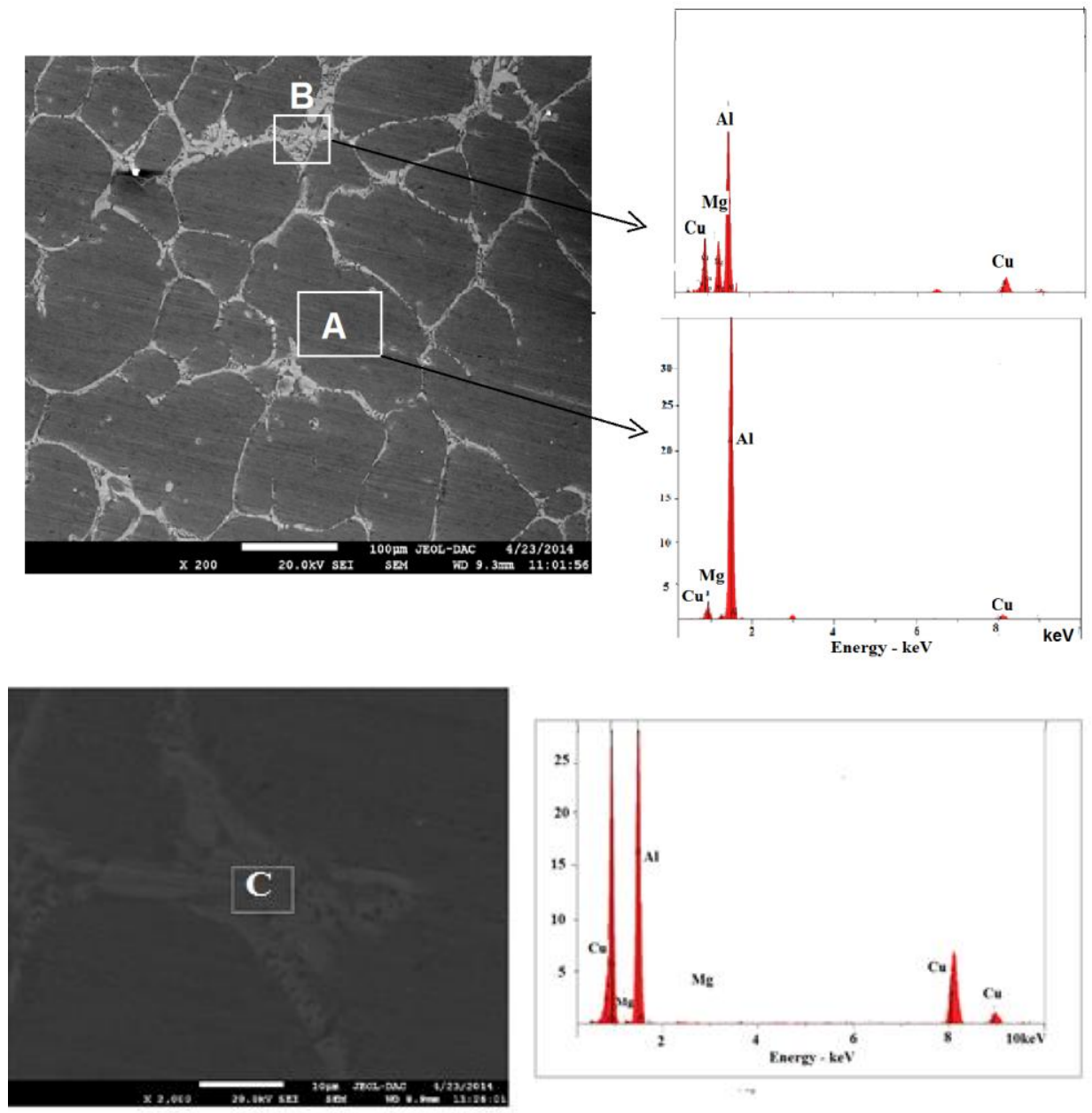

Fig. 7. Microstructures and typical EDS profiles of $\mathrm{Al}-3.3 \mathrm{wt} . \% \mathrm{Cu}-1 \mathrm{wt} . \% \mathrm{Mg}$ alloy marked by $\mathrm{A}$ and $\mathrm{B}$ and $\mathrm{Al}-3.3 w t . \% \mathrm{Cu}-2 \mathrm{wt}$.\%Mg alloy marked by $\mathrm{C}$ (After DSC treatment). 
Based on the $\mathrm{Al}-\mathrm{Cu}-\mathrm{Mg}$ phase diagram [28], the solid solubility of $\mathrm{Mg}$ is relatively low at room temperature in aluminum alloys. Therefore, the concentration of $\mathrm{Mg}$ at the interface of the solid/liquid phases was certain increased correspondingly during the solidification proceeds.

The Vickers hardness value of $\mathrm{Al}-3.3 \mathrm{wt} . \% \mathrm{Cu}-1$ wt. $\% \mathrm{Mg}$ and $\mathrm{Al}-3.3 \mathrm{wt} . \% \mathrm{Cu}-2$ wt.\% Mg alloys are presented in Table 5. All samples are aging for various time at $150{ }^{\circ} \mathrm{C}$ . Vickers hardness measurements were carried out in order to investigate the effect of mechanical properties with the small addition of magnesium. The Vickers hardness value of sample of $\mathrm{Al}-3.3 \mathrm{wt} . \% \mathrm{Cu}-2 \mathrm{wt} . \% \mathrm{Mg}$ alloy is slightly lower than that of $\mathrm{Al}-3.3 \mathrm{wt} . \%$ $\mathrm{Cu}-1 \mathrm{wt} . \% \mathrm{Mg}$ alloy. We concluded that the hardening observed is due to the formation of the phase $S^{\prime}$ which is converted into the hardening phase $S$ in order to obtain the maximum hardening in these alloys. values of the microhardness with the prolongation of aging at $150{ }^{\circ} \mathrm{C}$, is directly attributed to the decrease in the amount of precipitated phases and in particular, the metastable phase $\mathrm{S}$ 'and the precipitation of equilibrium phases S. The study of Eskin [29] explained the hardening and precipitation in the Al-Cu$\mathrm{Mg}-\mathrm{Si}$ alloying system. The composition and hardening phase in $\mathrm{Al}-\mathrm{Cu}-\mathrm{Mg}-\mathrm{Si}$ alloys containing $2.5 \%-4.5 \% \mathrm{Cu}$, are considered with respect to the chemical composition of the supersaturated solid solution.

Table 5. The value of Vickers hardness as a function of aging time at $150{ }^{\circ} \mathrm{C}$ of $\mathrm{Al}-$ $3.3 w t . \% \mathrm{Cu}-1 w t . \% \mathrm{Mg}$ and $\mathrm{Al}-3.3 w t . \% \mathrm{Cu}-2 \mathrm{wt} \% \mathrm{Mg}$ alloys.

\begin{tabular}{lcc}
\hline & $\mathrm{Hv}\left(\mathrm{Kg} / \mathrm{mm}^{2}\right)$ & \\
\hline Aging time $/ \mathrm{min}$. & $\mathrm{Al}-3.3 \% \mathrm{Cu} 1 \% \mathrm{Mg}$ & $\mathrm{Al}-3.3 \% \mathrm{Cu} 2 \% \mathrm{Mg}$ \\
\hline 0 & $109.72 \pm 2.35$ & $109.62 \pm 2.33$ \\
300 & $115.00 \pm 2.22$ & $113.5 \pm 2.14$ \\
600 & $115.20 \pm 2.12$ & $114.30 \pm 2.15$ \\
1200 & $116.05 \pm 3.01$ & $114.70 \pm 2.35$ \\
1800 & $118.31 \pm 3.11$ & $115.20 \pm 1.98$ \\
2400 & $123.11 \pm 2.63$ & $114.95 \pm 1.99$ \\
3000 & $125.21 \pm 2.41$ & $117.32 \pm 2.09$ \\
\hline
\end{tabular}

\section{Conclusion}

In this work, the small contents of magnesium and the heating rate of the nonisothermal transformation in the alloy $\mathrm{Al}-3.3 \mathrm{wt} . \% \mathrm{Cu}$ was studied. Several experimental methods suited to this kind of scientific research, to follow the various structural, and to try to understand the kinetics of various phenomena that occur was used Magnesium in the $\mathrm{Al}-\mathrm{Cu}$ alloy mainly precipitated to the grain boundaries during the process of transformation and formed ternary $\mathrm{Al}_{2} \mathrm{CuMg}$ phase. The DSC curves show the formation two phases $\mathrm{S}$ 'and $\mathrm{S}$, with a mean activation energy 154.57 and $154.82 \mathrm{~kJ} / \mathrm{mol}$ for $\mathrm{Al}-3.3 \mathrm{wt} . \% \mathrm{Cu}-1 \mathrm{wt} . \% \mathrm{Mg}$ and $\mathrm{Al}-3.3 \mathrm{wt} . \% \mathrm{Cu}-2 \mathrm{wt} . \% \mathrm{Mg}$, respectively. The value of Avrami coefficient (n) for $\mathrm{S}^{\prime}$ and $\mathrm{S}$ phases is 1.4 ; which may correspond to a phase transformation mechanism driven by the diffusion. The rate of discontinuous precipitation reaction decreases with the concentration of $\mathrm{Mg}$ increases. 


\section{References}

[1] G. B. Brook: Precipitation in Metals, Special Report No. 3, Fulmer Research Institute, UK, 1963.

[2] G. B. Brook, B. A. Hatt: The Mechanisms of Phase Transfer in Crystal Solids, Manchester, Institute of Metals, London, 33, 1969, 82.

[3] S. Schumann, H. Friedrich, Magnesium Alloys 2003, Materials Science Forum, 2003, 51: 419- 422 .

[4] L. Schlapbach, A. Zuttel: Nature, 414, 6861 (2001) 353-358.

[5] S. P. Ringer, G. R. Quan, T. Sakurai: J Mater Sci Eng A, 250 (1998) 120-126.

[6] A. Somoza, A. Dupasquier, I. J. Polmear, P. Folegati, R. Ferragut: Phys Rev B, 61 (2000) 14454-14463.

[7] S. C. Wang, M. J. Starink: Acta Materialia, 2007, 55:933-941

[8] H. Perlitz, A. Westgren: Arkiv Kemi Mineral Geol B, 16 (1943) 1.

[9] S. C. Wang, M. J. Starink: J Mater Sci Eng A, 386 (2004) 156-163.

[10]F. Cuisiat, P. Duval, R. Graf: Scr Metall, 18 (1984) 1051-1056.

[11]L. F. Mondolfo: Aluminum Alloys, 518 (1976).

[12]C. Wolverton: Acta Mater, 49 (2001) 3129-3142.

[13] T. V. Shchegoleva, N. N. Buinov: Soviet physics, crystallography, 12 (1967) 552 555.

[14]H. Liang, T. Kraft, Y. A. Chang: J Mater Sci Eng A, 292 (2000) 96-103.

[15] J. Yan, L. Chunzhi, Y. Minggao, J. C. L. Yan, Y. Minggao: J Mater Sci Lett, 9 (1990) $421-424$.

[16] R. K. W. Marceau, C. Qiu, S. P. Ringer, C. R. Hutchinson: J Mater Sci Eng A, 546 (2012) 153-161.

[17] M. J. Starink: Int Mater Rev, 49 (2004) 191-226.

[18]F. Lefebvre, S. C. Wang, M. J. Starink, I. Sinclair: Mater Sci Forum, 1555 (2002) 396-402.

[19] S. C. Wang, F. Lefebvre, J. L. Yan, I. Sinclair, M. J. Starink: J Mater Sci Eng A, 431 (2006) 123-136.

[20]H. Lu, P. Kadolkar, K. Nakazawa, T: Ando, C. A. Blue: Metall Mater Trans A, 38 (2007) 2379-2388.

[21] S. C. Wang, M. J. Starink, N. Gao: Scr Mater, 54 (2006) 287-291.

[22]N. Chobaut, D. Carron, J. M. Drezet: J Alloys Compd, 654 (2016) 56-62.

[23] N. Khan, M. J. Starink: Mater Sci Forum, 277 (2006) 519-521.

[24]H. E. Kissinger: Analytical Chemistry, 29 (1957) 1702-1706.

[25] J. L. Yan: Strength Modelling of Al-Cu-Mg Type Alloys, PhD Thesis. University of Southampton; 2006. https://eprints.soton.ac.uk/68691/1/Jialin_Yan_PhD_thesis.pdf

[26] J. A. Augis, J. E. Bennett: J Therm Anal Calorim, 13 (1978) 283-292.

[27]I. Manna, S. K. Pabi, W. Gust: Int Mater Rev, 46 (2001) 53-91.

[28] S. C. Wang, M. J. Starink: Int Mater Rev, 50 (2005) 193-215.

[29]D. G. Eskin: Mater Sci Forum, 396, (2002) 917-922.

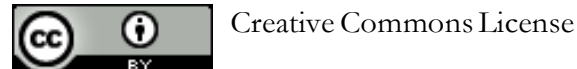

This work is licensed under a Creative Commons Attribution 4.0 International License. 